\title{
JOURNAL OF MAMMALOGY
}

Published Quarterly by the American Society of Mammalogists

\begin{tabular}{lll}
\hline VoL. I & NOVEMBER, 1919 & No. 1 \\
\hline
\end{tabular}

\section{BATS FROM MOUNT WHITNEY, CALIFORNIA}

\section{By Glover M. Allen}

In July, 1915, it was the writer's privilege to accompany Prof. Theodore Lyman on a brief expedition to Mount Whitney, the highest peak in the United States outside of Alaska, lying near the southern end of the Sierra Nevada of California. Starting from Lone Pine, at the eastern foot, we ascended to the upper limit of timber and there camped for a weck or more by the outlet of a mountain lake, at an altitude of about 11,000 feet. In successive evenings, four species of bats were secured at this camp, one of which proves to be an unsuspected new species, apparently related to Myotis lucifugus. The following brief notes are further offered as amplifying slightly the distributional data lately published by Mrs. Hilda W. Grinnell in her excellent Synopsis of the Bats of California (Univ. of Calif. Publ., zool., 1918, vol. 17, p. 223-404, pl. 14-24). All the specimens obtained were, through Doctor Lyman's generosity, given to the Museum of Comparative Zoölogy, at Cambridge, to the authorities of which I am indebted for permission to publish this report.

\section{Myotis yumanensis sociabilis H. W. Grinnell}

TEJON BAT

This form of the Yuma bat is characterized by Mrs. Grinnell as intermediate in color between typical yumanensis and its subspecies saturatus. She indicates its range as the "semi-arid Transition and Sonoran zones in [southern] California west and north of the southeastern deserts." On July 16, a bat which seems referable to this race was shot just above our camp at 11,000 feet on Mount Whitney,

JOURNAL OF MAMMALOGT, VOL. $x$, NO.1 
the highest recorded altitude for it in the state (though Mrs. Grinnell records one from 8500 feet in the San Bernardino Mountains). A second individual was captured at Lone Pine at the foot of the mountain, a few days later. Both are males.

In her Synopsis of the Bats of California, Mrs. Grinnell cites but a single specimen of typical yumanensis from that State, namely, one from Carroll Creek, Inyo County. In view of the implied distribution of this form east of the desert divides, I at first was inclined to refer the above specimens to it, but thanks to the generous interest of Mr. A. Brazier Howell, of Covina, California, I have been able to compare them with typical yumanensis from near Potholes, a short distancefrom Fort Yuma, Imperial County, the type locality. The skin from Mount Whitney is noticeably darker, with slightly darker membranes, thus inclining toward the race saturatus. There is a very notable difference, apparent in both skin and alcoholic, by which the two specimens from Inyo County are further distinguished, namely, the much larger thumbs with their longer, more curving claw. The thumb of typical yumanensis is nearly 1.5 to $2 \mathrm{~mm}$. shorter, a difference very apparent on comparison. Although direct comparison with typical specimens of sociabilis has not been made, it is clear that our Mount Whitney and Lone Pine examples cannot be referred to yumanensis proper, and hence doubtless represent sociabilis, the subspecies intermediate in position between it and saturatus.

Myotis albicinctus sp. nov.

\section{WHITE-EDGED BAT}

Type.-An adult male, skin (and skull, temporarily mislaid), 11747 Mus. Comp. Zoöl., from 11,000 feet altitude at the upper limit of timber, Mount Whitney, California, July 14, 1915.

Characters.-A bat of the size and proportions of $M$. lucifugus but very pallid, with conspicuous white border to the wing membranes, broadest between the fifth finger and tarsus. Skull like that of $M$. lucifugus but the two small anterior premolars of the upper jaw relatively larger, the first drawn decidedly within the posterior border of the canine, by which it is thus partly concealed in side view.

Color.-The type is a very pale clear sandy above, nearest the "pale buff" of Ridgway's 1912 Nomenclature of Colors, very slightly paler or grayer on the head; below clear and contrasting white, the gray bases of the hairs showing through on the throat. The basal portion of the fur of both surfaces is dark slaty, paler or grayish at the throat.

The ears are blackish as is also the greater part of the wing membranes. The posterior edge of the wing from the tip of the longest (third) digit to the ankle 
has a pronounced white border, narrow at the tip of the wing and not sharply defined, but from the tip of the fifth finger to the tarsus, it is broad $(1.5 \mathrm{~mm}$. in the dry skin), very sharply and contrastingly marked off. The uropatagium is dusky on the basal third, passing into whitish on the distal two thirds, with a clearer white edge.

Membranes.-The ears and tragus are practically as in $M$. lucifugus, and minutely haired. The fur of the body extends very slightly on to the base of the uropatagium, but is sharply limited at the sides of the body. The foot is relatively large as in $M$. lucifugus, the ealcar long and slender, unkeeled, ending in a minute projecting lobule. The extreme tip of the tail is free.

Skull.-Unfortunately the skull of the type has been temporarily mislaid. The skull of a second specimen, however, (1023, coll. of A. B. Howell) from Mono County, California corresponds closely in size and shape with that of $M$. lucifugus altipetens, but is at once distinguished by the relatively larger and blunter first and second upper premolars $\left(p m^{2}, p m^{3}\right)$. In $M$. lucifugus and its western race both are fully visible in side view, and stand practically in the line of the tooth row, the posterior tooth with perbaps one half the cross-section area of the anterior. In M. albicinctus, however, the larger anterior tooth is distinctly drawn in from the tooth row and shifted slightly forward, so that the anterior third of its base is nearly concealed by the base of the canine when viewed in profile. The second premolar is distinctly larger relatively, in cross section, than in $M$. lucifugus. As in the latter, and in contrast to $M$. subulatus, the lower incisors are but very slightly imbricate.

Measurements.-The type measured before skinning: total length, $86 \mathrm{~mm}$; tail, 42.5; hind foot, 9; ear from meatus, 15; forearm, 37; tibia (dry), 16 . The specimen collected by Mr. A. B. Howell in Mono County, California, measured: total length, $91 \mathrm{~mm}$.; tail, 41; hind foot, 11; ear, 14; alar expanse, 255. Its forearm measures $38 \mathrm{~mm}$., tibia, $\mathbf{1 7 . 5}$.

The skull of the latter specimen (1023, coll. A. B. Howell), measures: greatest length, 15; basal length, 12.5; palatal length, 7; upper tooth row, $i^{1}$ to $m^{3}, 6.5$; width outside $m^{3}, 5.8$; interorbital width, 3.8 ; zygomatic width, 9 ; mastoid width, 7.5; lower tooth row, $i_{1}$ to $m_{3}, 7$.

Remarks.-This very beautiful new species is at once distinguished from any of the described forms of North American Myotis by its pale buff coloration above, contrasting with the white lower surface, and by the conspicuous and sharply defined white border of the wing membranes, and the silvery uropatagium.

The type was shot at dusk as it was flying down the slope above our camp at 11,000 feet on Mount Whitney. The locality was just above a clump of pines that formed the upper limit of timber at the lower end of a large valley encroaching upon the main peak. A rushing mountain stream dashed past at this point and a large snow bank still remained near by in mid-July.

The skull of this specimen after brief examination, was put aside for cleaning but has been unfortunately mislaid. I had hesitated to de- 
scribe the species without comparison of the skull, but the capture of a second example at Mammoth, Mono County, California, by Mr. A. Brazier Howell of Covina, California, has happily made this possible. Both Dr. and Mrs. Joseph Grinnell, who have seen these two skins, were inclined to refer them to $M$. lucifugus altipetens, though recognizing that they are quite different. Mr. Howell has very generously loaned me his specimen (taken on August 2,1917) and it agrees in every essential with the type, showing the same pale buffy coloration above, pure white below, and conspicuous white border to the wing membrane. In the dry skin, the uropatagium is a trifle darker owing to its not being as completely spread. The beautifully prepared skull has made possible a description of the conspicuous difference in the upper premolars as compared with $M$. lucifugus altipetens, a specimen of which, identified by Doctor and Mrs. Grinnell, the Museum has from Mount Tallac, California. In size and details of external structure this species very closely resembles $M$. lucifugus and $M . l$. altipetens but in its coloration and in the relations of the first two upper premolars it is widely different and is unquestionably a wholly distinct species. As lately shown by Mrs. Grinnell, the race altipetens is clearly only a pallid subspecies of Myotis lucifugus, from which it chieffy differs in its tawnier coloration. The dark shoulder spot is a distinguishing mark of the species, but no trace of such a contrasting spot is found in $M$. albicinctus.

The pallid coloration of this bat may indicate that its main range is in the desert country chiefly east of the Sierras.

\section{Myotis longicrus interior Miller}

\section{INTERIOR LONG-LEGGED BAT}

Two males were shot on different evenings (July 14 and 17) at our camp at 11,000 feet. One is much darker in coloration than the other, apparently an immature though full-sized individual. The other is a brighter tawny-olive than a specimen from Hot Springs Pass, Mono County, in the Museum collection, taken as representing typical longicrus. I have followed Mrs. Grinnell in referring both to the subspecies interior. In her Synopsis of the Bats of California, she records it from the "arid Upper Sonoran, Transition, and lower Canadian zones" from Mono County southward. The present capture extends the limits of range to a record altitude. Our first specimen was shot shortly after sundown while it was flying about among 
the tops of the pines surrounding the camp. The flight is rather slow and weak as compared with that of $M$. lucifugus. In addition to its longer tibia and smaller hind foot, this species is easily distinguished from the lucifugus group by its well-keeled calcar.

\section{Eptesicus fuscus (Beauvois)}

LARGE BROWN BAT

At our 11,000-foot camp, one or two large brown bats were seen nearly every evening, distinguished by their size and relatively slow steady flight. Of those shot only one, an adult male, was retrieved. It is quite identical in color with two females shot at Lone Pine, at the base of the mountain, and is not to be distinguished from eastern skins. Thus the wide geographical range of the species corresponds with its altitudinal distribution.

General remarks.-It is probably significant that all five specimens obtained at 11,000 feet on Mount Whitney, representing four species of bats, are males. The presence of Myotis longicrus interior, $M$. yumanensis sociabilis, and Eptesicus fuscus above the Transition or Lower Canadian zones appears to be unrecorded in California, yet all three were collected in what would be considered for ground-living mammals, a boreal (Hudsonian) zone. This wide range in altitudinal distribution implies a certain disregard for the zonal limits which is probably due to temporary increase in distributional area of insect life, causing a temporary invasion by bats from the lesser altitudes. As recorded by Mrs. Grinnell, of sixty-one bats of the race Myotis yumanensis sociabilis collected at Fort Tejon, July 21 to 25 , all the adults were females, thus indicating, as Mrs. Grinnell suggests, "that with the approach of summer the full-grown [adult] males leave the colony and forage singly at higher elevations." That the breeding females are more strictly confined to their proper "life zones" seems likely and is corroborated by our observations on Mount Whitney, where the few specimens taken proved to be males. It is well known that the upper levels of mountains abound in insects, many of which are wafted up by convectional diurnal air currents from below, so that during the midsummer period they would form an attraction to insectivorous bats, and thus afford cause for a local and seasonal invasion by the non-breeding individuals. It was unexpected that we should not have taken Myotis lucifugus altipetens on Mount Whitney, a species whose normal range includes high altitudes. 